\title{
3D PRINTING OF A LOWELL MAKES MASK IN PLA
}

\author{
${ }^{1}$ Elmoutawakkil Nidal https://orcid.org/0000-0003-2524-9286 \\ ${ }^{2}$ Seffar Alae-Eddine https://orcid.org/0000-0002-3741-4341 \\ ${ }^{3}$ Elmoutawakkil Dalal \\ ${ }^{3}$ Hacib Nabil \\ ${ }^{1}$ Bellemkhannate Samira \\ ${ }^{1}$ Casablanca's Dental Consultation and Treatment Center, Casablanca, Morocco \\ ${ }^{2}$ University Hospital Center Ibn Rochd, Casablanca, Morocco \\ ${ }^{3}$ The private sector in orthodontics and implantology, Casablanca, Morocco \\ nidalelmoutawakkil@yahoo.fr
}

Relevance: The new pandemic crisis caused by the Covid19 virus has led to a global shortage of personal protective equipment including FFP2 masks necessary for the exercise of professionals in direct contact with positive patients.

Objective: 3D print a PLA mask similar to the FFP2 mask with the addition of an ULPA filter

Methods. The designed mask is based on the general morphology of the FFP2 standard. This is how we downloaded the prototype of the «LOWELL MAKES». We have adapted this prototype to our craniofacial dimensions on the «Meshmixer» software, to finally export the prototype in STL format to print it by fused deposition modeling (FDM) via the 3D printer «XYZ Junior 1.0» equipped with a PLA (polylactic acid) filament.

Results. The total duration of the printing of the full mask (the cover, the body of the mask, and the retentive filter grid) was around 4h30 min. Regarding the choice of the filter, we opted for two solutions, the first to cut an FFP2 mask and to use the parts obtained as being filters (doubled), the second being a commercial ULPA or HEPA filter. A ULPA (Ultra Low Penetration Air) filter can theoretically filter dust, pollen, and bacteria from the air with an efficiency of $99.999 \%$ thanks to a size of 0.1 microns. Remember that the average size of the Covid-10 virus is around $0.1 \mu \mathrm{m}$ and that the porosity of the FFP2 mask allows particles to be filtered with a diameter of around $0.6 \mu \mathrm{m}$ at $94 \%$. In order to maximize the filtering effect while wearing this mask, we opted for the interposition of a ULPA filter covered by an FFP2 filter. We tested the tightness of this mask by checking for side leaks by maintaining a stabilized sheet on the outer cover by suction during inhalation. We have also added to the edges of the mask in contact with the face a peripheral silicone seal, polymerized on the face, to avoid any marks or scars after removal of this mask while increasing the comfort of the practitioner. The protocol that we chose by superimposing two filters (the first having a porosity of $0.6 \mu \mathrm{m}$ and the second of $0.1 \mu \mathrm{m}$ ) allowed us to potentiate the filtration. This allowed the filter to be used for 40 hours. The total cost price of the mask is around $9 €$.

Conclusions. The «open source» community makes it possible to popularize 3D printing while making it easier for any 3D printer owner to appropriate their protective equipment at a reduced price, however, intellectual property remains a concern, in particular for medical parts that cannot be procured promptly during a pandemic crisis similar to that caused by the Covid-19 virus.

Keyword: Lowel Makes mask, PLA, 3D printing, ULPA filter.

Relevance. In the context of the new pandemic caused by the COVID-19 virus, the quarantine measures adopted have raised tensions and fears among the general public; A reckless consequence of this is the impulse purchase of personal protective equipment (PPE), leaving the health professionals who need it most in short supply; Besides, facing the globally declared quarantine state, the factories responsible for manufacturing this equipment have suspended their activity as well as their export. This is how members of the global 3D printing community embarked on the design of several reusable PPE with interchangeable filters, mainly manufactured using high-temperature filament extrusion office printers, the cost of which remains reduced. Until today, the PPE that is still needed mainly includes surgical masks, FFP2 masks, and respiratory hoods with controlled air purification. However, since this PPE is intended to be reusable, careful consideration should be given to compatibility with available disinfection techniques while ensuring that all such devices are monitored on an ongoing basis for tightness and condition before each use.

To ensure the best fit, customization of these masks can be achieved in several ways:

- by printing several sizes

- by experimenting with flexible materials

- by surface scanning the faces to virtually adjust these masks on an individual basis.

Although this individualized approach may limit the production throughput, the improvement in final rendering and wearing comfort may justify this impact on throughput [1].

A 2004 study conducted by the National Institute for Occupational Safety and Health, involving 3,997 heads and a second study in 2005 suggesting a workplace protection factor (WPF) for respiratory masks, found together that there were substantial and significant differences between the effectiveness of onesize-fits-all face masks. The WPF regression analysis 
found the most important of the 12 facial dimensions to be bigonial width, face width (bizgomatic width), face length (chin-saddle length), and nose protrusion (Fig. 1). Although not formally tested, the 2005 data was almost normally distributed and suggested a basis for three potential mask sizes. For the design of our model, we opted for a medium to large size mask for testing $($ Chin-Sellion $=132 \mathrm{~mm}$, bigonial $=96 \mathrm{~mm}$, nose $=43 \mathrm{~mm}$ ) [2].

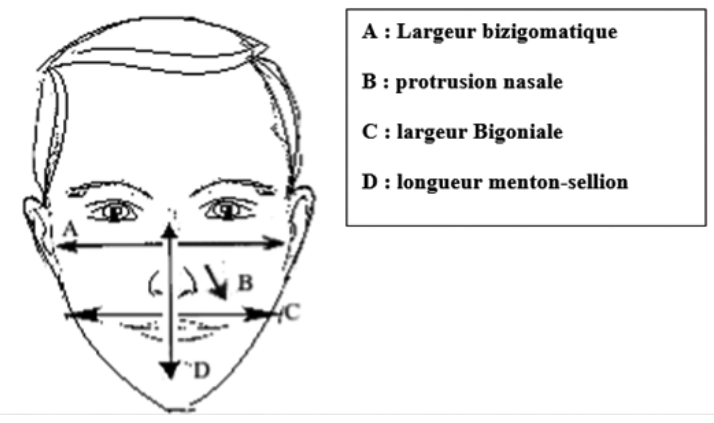

Fig. 1. Diagram of the four major metric values for the adaptation of the mask [3]

Nowadays, there are several versions of 3D printed masks, in parallel, The «FDA» (administration of food and drugs), the «NIH» (the national institute of health), and the «United States Veterans Association» are working together to validate and certify several prototypes of FFP2 masks, some of which are currently being tested. In the meantime, and on a more individual scale, many designs of face masks have been proposed and tested by researchers, physicians, and commercial entities with varying degrees of success. In any case, end users should clearly understand that only prototypes are available at this point and that they must pass several fit tests to assess their quality as PPE.

3D printing transmits a digital file to an additive manufacturing device such as a $3 \mathrm{D}$ printer to create a three-dimensional solid object layer by layer. Digital files are often made available to the general community in the creator's space in «STL», «OBJ» or even «CAD» formats. Digital files are processed, edited, and prepared in software such as «GrabCAD», «Meshmixer», «iiiSlic3r» and «Meshlab».

The Copper3D NanoHack Mask [4] illustrates the limitations of community-generated designs and wants design improvements based on local testing. This mask can be printed with a polylactic acid (PLA) filament as a flat part and is intended to be then manually assembled into its final three-dimensional configuration after heating to 55 to $60^{\circ} \mathrm{C}\left(131\right.$ to $\left.140 \mathrm{~F}^{\circ}\right)$ by forced hot air (e.g. a hairdryer) or by immersing it in hot water (Fig. 2). In particular, all joints should be manually sealed to ensure an airtight fit. The mask features a simple air inlet port into which two reusable filters can be inserted, with a screw cap to hold them in place. This design has several drawbacks, due to its flat architecture, only one mask can be printed by most desktop printers at a time, which limits the throughput of manufacturing. Practically, initial tests have shown difficulty in folding these masks created using conventional PLA filament, with large gaps along the hard-to-mitigate knuckles. If sealed successfully, the mask may provide limited airflow for some users and a second breathing port can be envisioned by mirroring the first port on the design software. Due to these multiple limitations, this mask is currently undergoing revisions by the original designer.

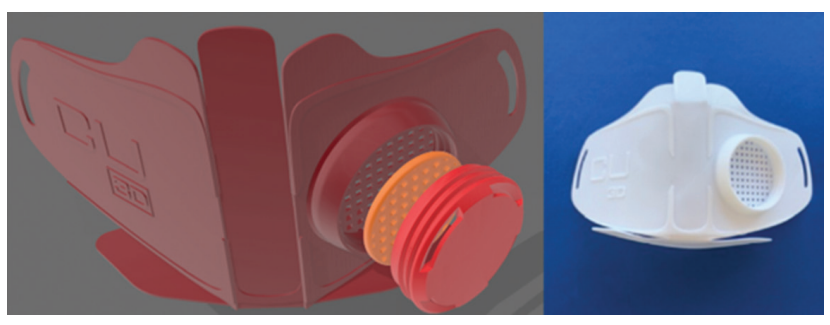

Fig. 2. NanoHack Copper3D mask model [4]

The Thingiverse Kvatthro [5] user-designed HEPA mask can also be fabricated using most desktop printers. PLA filament is suggested due to the ability to adapt the mask to the individual wearer after exposure to heat, which is important to ensure the best possible seal under working conditions. This device is available in male and female versions and leaves room to insert an interchangeable HEPA filter into a port on the front of the mask (Fig. 3).

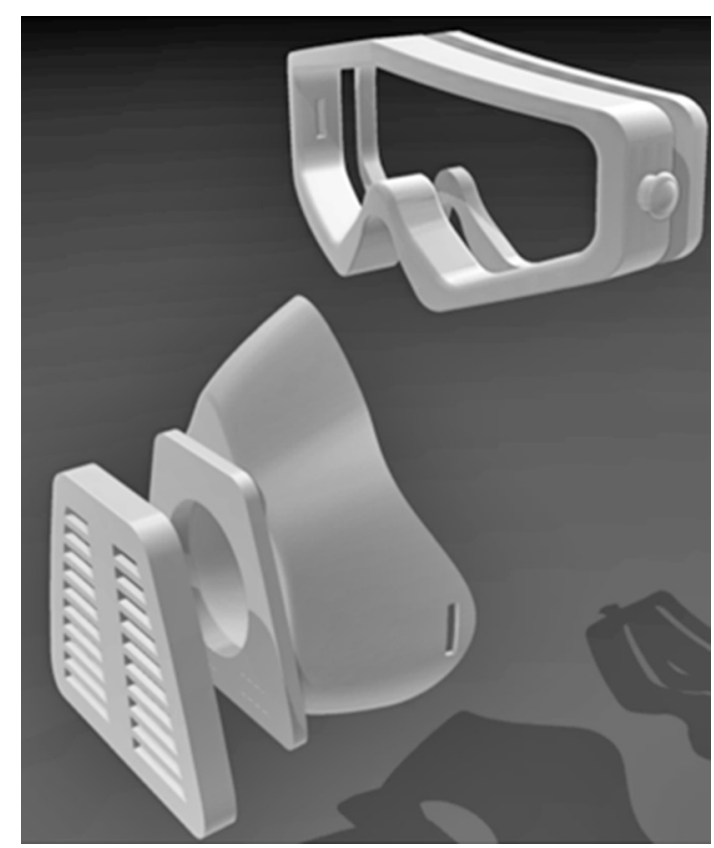

Fig. 3. HEPA mask design with a box for inserting the filter [5]

A similar design has been proposed by the Chinese company Creality [6], with a different configuration of the filter holder, intended for the insertion of layers of folded tissue or filters (Fig. 4). 


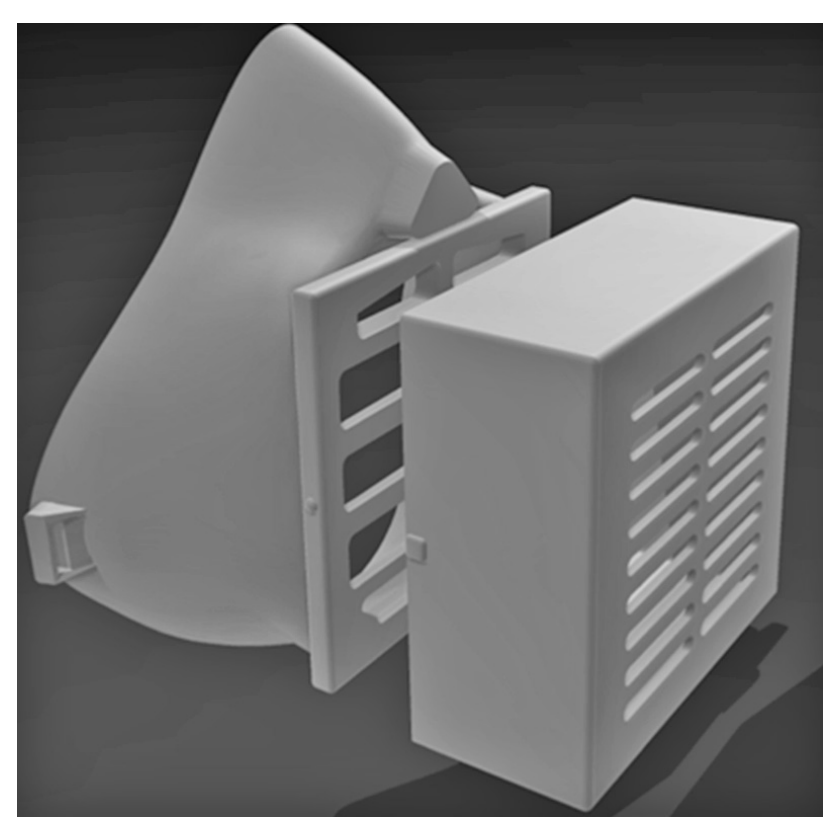

Fig. 4. Creality mask and goggles design [6]

The Lowell Makes mask is a variation of the replaceable front filter design which offers the advantage of printing without supports or adhesion [7] (Fig. 5). Although these masks are an alternative to FFP2 masks, they are not approved by the «FDA» or «NIOSH» or any other federal or state regulatory agency. They should not be considered as replacing an FFP2 mask, especially if the latter is available [8].

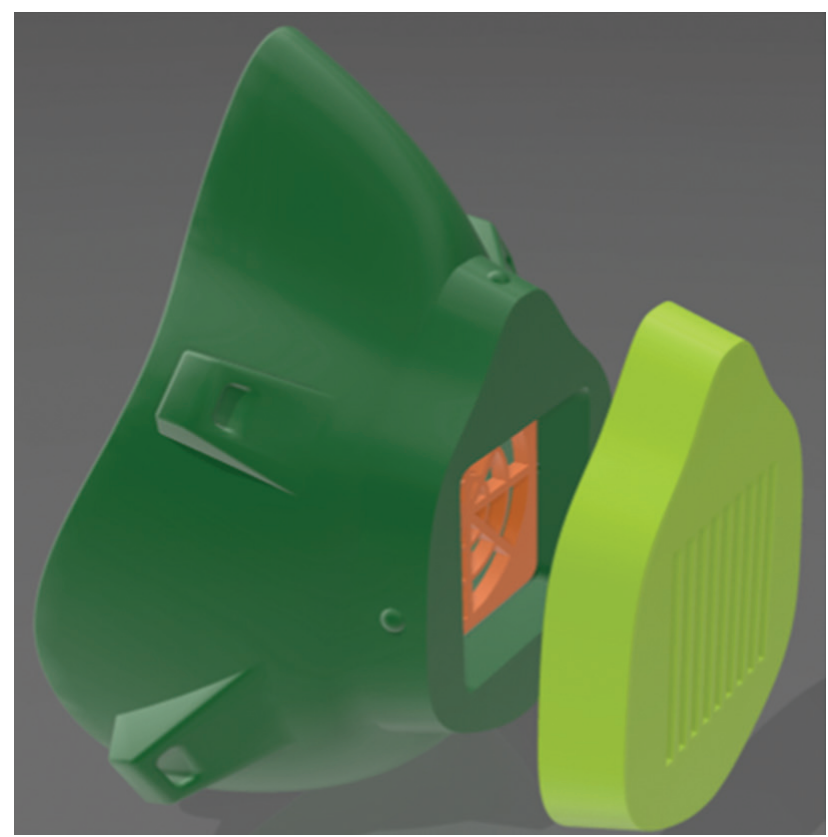

Fig. 5. Lowell Makes mask design, with the filter held in place by a grid inside the mask and a cap on the front of the mask [7]

\section{MATERIAL AND METHOD}

The designed mask is based on the general morphology of the FFP2 standard. This is how we downloaded the prototype of the «LOWELL MAKES» mask available on the platform of the same firm. We have adapted this prototype to our craniofacial dimensions on the «Meshmixer» software, to finally export the prototype in STL format to print it by fused deposition modeling (FDM) via the printer available in the department of removable prosthodontics in the dental consultation and treatment center of Casablanca (Fig. 6).

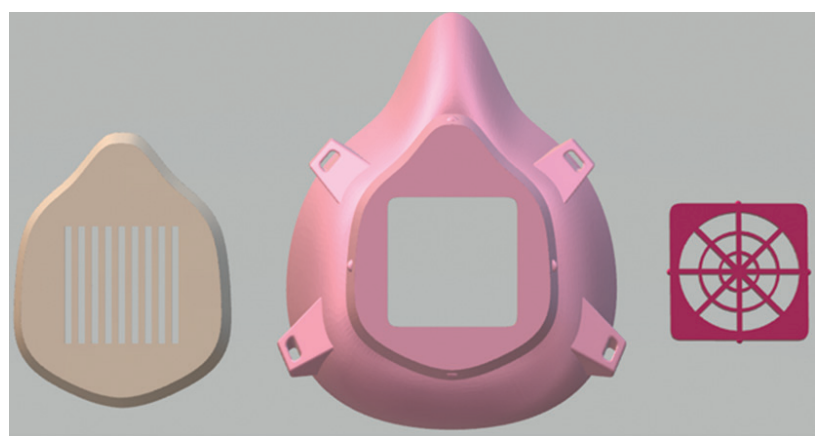

Fig. 6. Adaptation of the Lowell Makes mask prototype to our facial proportions [7]

\section{RESULTS AND DISCUSSION}

After exporting the STL file of each element making up the mask (the cover, the body of the mask, and the retentive filter grid) to the «XYZ Junior 1.0»3 3 printer equipped with a PLA (polylactic acid) filament. The total duration of the printing of the full mask was around $4 \mathrm{~h} 30 \mathrm{~min}$; the final rendering of the mask being smooth and free of any artifact, no finishing took place (Fig. 7).

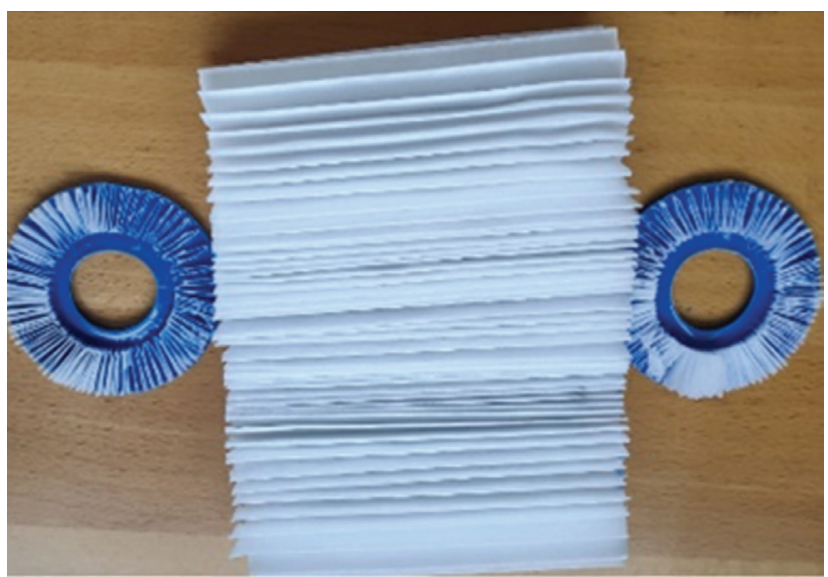

Fig. 7. The final rendering of the mask being smooth and free of any artifact, no finishing took place

Regarding the choice of the filter, we opted for two solutions, the first to cut an FFP2 mask and to use the parts obtained as being filters (doubled), the second being a commercial ULPA or HEPA filter cut from a sold coil in large surfaces specializing in air filtration (Fig. 8).

HEPA (high-efficiency particulate air) filtration is a standard developed by the United States Energy Commission. HEPA filters are the world's most efficient way to filter the air from dirt, pollens, bacteria, and any particle in the air larger than $0.3 \mu \mathrm{m}$. They are used in hospitals, 


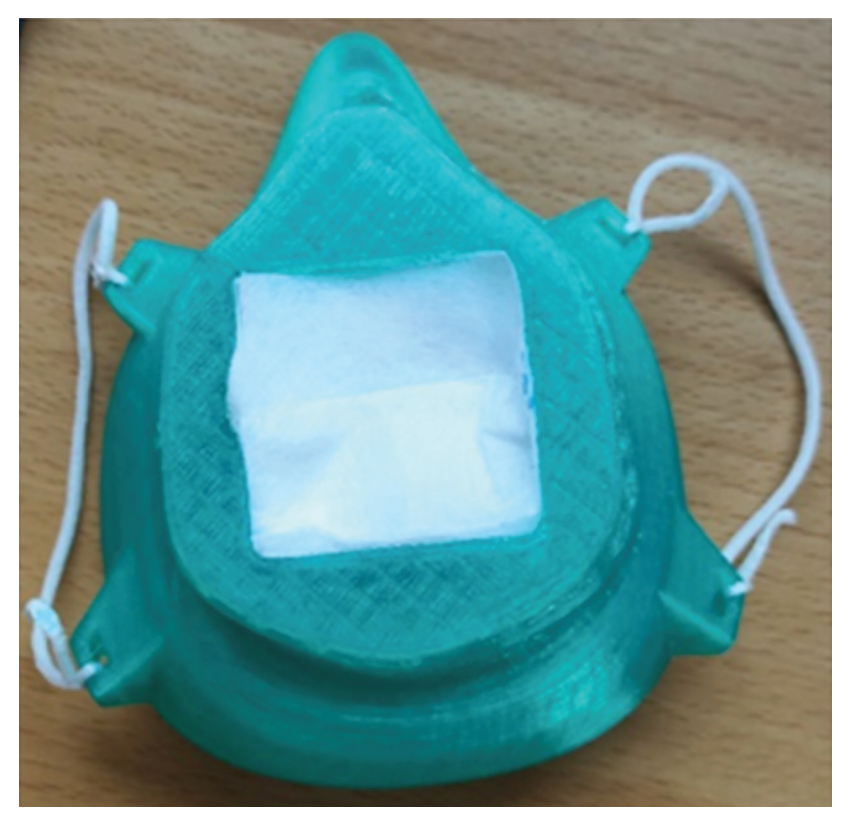

Fig. 8. Placement of the HEPA filter in the Lowells Makes mask printed in PLA cut from a coil

pharmaceutical companies, laboratories, and electronics companies to remove all fine dust. To qualify as HEPA, a filter must remove $99.97 \%$ of 0.3 -micron particles.

A ULPA (Ultra Low Penetration Air) filter can theoretically filter dust, pollen, and bacteria from the air with an efficiency of $99.999 \%$ thanks to a size of 0.1 microns. Remember that the average size of the Covid-10 virus is around $0.1 \mu \mathrm{m}$ and that the porosity of the FFP2 mask allows particles to be filtered with a diameter of around $0.6 \mu \mathrm{m}$ at $94 \%$.

In order to maximize the filtering effect while wearing this mask, we opted for the interposition of a ULPA filter (U15, U 17) covered by an FFP2 filter.

We tested the tightness of this mask by checking for side leaks by maintaining a stabilized sheet on the outer cover by suction during inhalation, to maximize this seal the two filters were taped to the outer face of the orifice of the mask. Mask and the cover were fixed with tacks (Fig. 9).

Finally, to make it easier to wear the mask, we attached elastic bands to it in two ways, first putting an elastic on each side (left and right) to wear it around the outer pavilion of the ears, however, this method caused lesions and injuries to the ears, the second method being to adapt the length to the coronal diameter and to have an elastic band per side (top and bottom) making sure to cross them during the wearing, this last method not only makes wearing the mask easier but also facilitates also its implementation for veiled personnel.

We have also added to the edges of the mask in contact with the face a peripheral silicone seal, polymerized on the face, to avoid any marks or scars after removal of this mask while increasing the comfort of the practitioner.
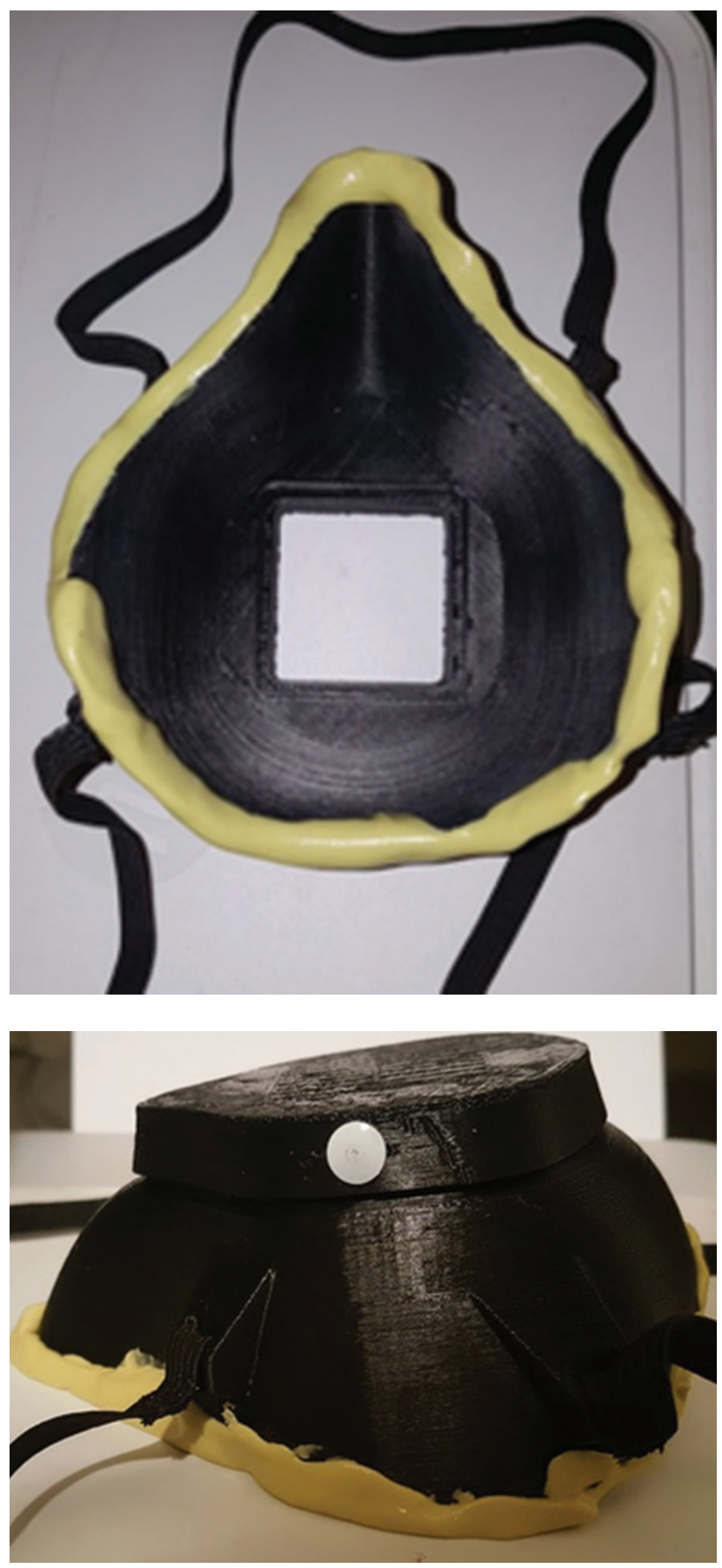

Fig. 9. Additional fixing of the cover using office tacks and addition of a heavy silicone flexible seal to the Lowells Makes mask printed in PLA

The French society of hospital hygiene (HF2H) as well as the WHO recommends changing the FFP2 mask after 8 hours of wearing or each time it is wet, taking into account the global shortage incurred during the past few months following the pandemic caused by the Covid-19 virus, the medical staff had to make reusable masks ready for disinfection [9].

The protocol that we chose by superimposing two filters (the first having a porosity of $0.6 \mu \mathrm{m}$ and the second of $0.1 \mu \mathrm{m}$ ) allowed us to potentiate the filtration while ensuring the judicious use of PPE, in fact instead of 
wearing conventionally the FFP2 mask for 8 hours, the decomposition of the latter offered 5 doubled portions allowing us to use it for 40 hours.

The disinfection of the mask begins with its disassembly on an operating field, the filters are discarded the external and internal surfaces are disinfected by spraying with $5 \%$ hypochlorite or using a surface disinfectant based on quaternary ammonium, the mask is then wiped and stored in a special box, taking into account the degradation of the PLA in contact with water, immersion remains prohibited.

The price of the mask (without filter) is $4 €$, in fact, a spool of PLA, costing on average $60 €$, allows the printing of 15 reusable masks.

A ULPA filter costs about $\$ 50$ to make 10 individual filters; Thus the total cost price of the mask is around $9 €$.

\section{CONCLUSION}

The «open source» community makes it possible to popularize $3 \mathrm{D}$ printing while making it easier for any $3 \mathrm{D}$ printer owner to appropriate their protective equipment at a reduced price, however, intellectual property remains a concern, in particular for medical parts that cannot be procured promptly during a pandemic crisis similar to that caused by the Covid-19 virus.

The lack of clinical experience requires the implementation of a codified protocol to scientifically test the validity of these $3 \mathrm{D}$ printed medical devices with the aim of future certification putting them on the same footing as FFP2 / FFP3 masks.

\section{REFERENCES}

1. Ramanathan K, Antognini D, Combes A, Paden M, Zakhary B, Ogino M, MacLaren G, Brodie D, Shekar $\mathrm{K}$. Planning and provision of ECMO services for severe ARDS during the COVID-19 pandemic and other outbreaks of emerging infectious diseases. Lancet Respir Med. 2020 May;8(5):518-26. DOI: 10.1016/ S2213-2600(20)30121-1

View at: Publisher Site: https://www.thelancet.com/ journals/lanres/article/PIIS2213-2600(20)30121-1/ fulltext

PubMed: https://pubmed.ncbi.nlm.nih.gov/32203711/ PubMed Central: https://www.ncbi.nlm.nih.gov/pmc/ articles/PMC7102637/

2. Ziqing Z, Coffey C, Roland BA. The Effect of Subject Characteristics and Respirator Features on Respirator
Fit. J.occup.Envir. Hyg. 2005 Dec;2(12):641-9. DOI: 10.1080/15459620500391668

View at: Publisher Site: https://www.tandfonline.com/ doi/abs/10.1080/15459620500391668

PubMed: https://pubmed.ncbi.nlm.nih.gov/16298949/

3. Provenzano D, Rao YJ, Mitic K, Obaid S.N, Pierce D, Huckenpahler J,Berger J,Goyal SH, Loew M.H. Rapid Prototyping of Reusable 3D-Printed N95 Equivalent Respirators at the George Washington University. Preprints. 2020 March: 2020030444. DOI: 10.20944/ preprints202003.0444.v1

View at: Publisher Site: https://www.preprints.org/ manuscript/202003.0444/v1

4. About NanoHack. Accessed 24 Mar 2020.

View at: Publisher Site: https://copper3d.com/ hackthepandemic/

5. HEPA Mask. Accessed 24 Mar 2020.

View at: Publisher Site: https://www.thingiverse.com/ thing:4222563

6. Makers Guide. Accessed 24 March 2020.

View at: Publisher Site: https://creality.com/info/makers-guide-3d-printed-face-mask-no-worries-on-maskshortage-and-virus-infection-i00248i1.html

7. COVID-19 Response. Accessed 24 March 2020.

View at: Publisher Site: https://lowellmakes.com/ covid-19-response/

8. Tino R, Moore R, Antoline S, Ravi P, Wake N, Ionita CN, Morris JM, Decker SJ, Sheikh A, Rybicki FJ, Chepelev LL. COVID-19 and the role of 3D printing in medicine. 3D Print Med. 2020 Apr 27; 6(1):11. DOI: 10.1186/s41205-020-00064-7

View at: Publisher Site: https://threedmedprint.biomedcentral.com/articles/10.1186/s41205-020-00064-7

PubMed: https://pubmed.ncbi.nlm.nih.gov/32337613/

PubMed Central: https:/www.ncbi.nlm.nih.gov/pmc/ articles/PMC7183817/

9. Société française d'Hygiène Hospitalière ( $\mathrm{SF} 2 \mathrm{H})$. Avis du 04 mars 2020 relatif aux indications du port des masques chirurgicaux et des appareils de de protection respiratoire de type FFP2 pour les professionnels de santé.

View at: URL: https:/www.sf2h.net/wp-content/uploads/2020/02/Avis-Masque-SF2H-SPILF-04.03.2020. pdf 


\title{
3D ДРУК «LOWELL MAKES» МАСКИ 3 PLA НИТКОЮ
}

\author{
${ }^{1}$ Ельмутаваккіл Нідаль, ${ }^{2}$ Сеффар Алае-Еддін, ${ }^{3}$ Елмутаваккіл Далал, \\ ${ }^{3}$ Хациб Набіл, 1Белемханнат Саміра \\ ${ }^{1}$ Стоматологічний консультаиійний і лікувальний центр Касабланки, Касабланка, Марокко \\ ${ }^{2}$ Університетська клініка Ibn Rochd, Касабланка, Марокко \\ ${ }^{3}$ Приватний сектор ортодонтії та імплантології, Касабланка, Марокко \\ nidalelmoutawakkil@yahoo.fr
}

Актуальність. Нова пандемічна криза, викликана вірусом Covid 19, призвела до глобальної нестачі засобів індивідуального захисту, включаючи маски FFP2, які необхідні для використання фахівцями, які перебувають в прямому контакті з Соvid позитивними пацієнтами.

Мета. 3D-друк PLA маски, аналогічної масці FFP2, з додаванням фільтра ULPA (Ultra Low Penetration Air).

Методи. Розроблена маска заснована на загальних морфологічних стандартах маски FFP2. Таким чином, ми завантажили прототип маски «LOWELL MAKES». Ми адаптували цей прототип до наших черепно-лицьових розмірів за допомогою програмного забезпечення «Meshmixer». В результаті, експортували прототип в формат STL для друку за допомогою методу FDM (fused deposition modeling / моделювання методом пошарового накладання розплавленої полімерної нитки) на 3D-принтері «XYZ Junior 1.0», оснащеному PLA (polylactic acid) ниткою.

Результати. Загальна тривалість друку повної маски (зовнішній шар, основа маски і сітка утримуючого фільтру) становила близько 4 год 30 хв. Що стосується вибору фільтра, ми використовували два варіанти: перший - вирізані, подвійні частини маски FFP2 використовували в якості фільтрів, другий - використовували комерційний фільтр ULPA (Ultra Low Penetration Air) або HEPA (High-efficiency particle absorption). Фільтр ULPA теоретично може фільтрувати пил, пилок і бактерії з повітря з ефективністю 99,999\% завдяки розміру пор 0,1 мікрон. Середній розмір вірусу Covid-10 становить близько 0,1 $\mu$, а пористість маски FFP2 дозволяє фільтрувати частки діаметром близько 0,6 $\mu \mathrm{m}$ в 94\% випадків. Щоб максимізувати ефект фільтрації при носінні цієї маски, ми вирішили використовувати фільтр ULPA, перекритий фільтром FFP2. Ми перевірили щільність цієї маски, перевіривши бічну відсутність герметичності, утримуючи стабілізований лист на зовнішній поверхні в результаті присмоктування під час вдиху. Ми також додали до країв маски, що контактує з лицем, периферійне силіконове ущільнення, яке полімеризоване на обличчі, щоб уникнути будь-яких слідів або шрамів після видалення цієї маски, одночасно збільшуючи комфорт практикуючого лікаря. Технологія, яку ми обрали - шляхом накладення двох фільтрів (перший 3 пористістю $0,6 \mu \mathrm{m}, \mathrm{a}$ другий $0,1 \mu \mathrm{m}$ ). Це дозволило нам посилити фільтрацію і використовувати фільтр протягом 40 годин. Загальна собівартість маски становить близько $9 €$.

Висновки. Спільнота відкритого програмного забезпечення дає можливість популяризувати 3D-друк, разом 3 тим дозволяє будь-якому власникові 3D-принтеру використовувати своє обладнання за зниженою ціною. Однак питання інтелектуальної власності, як і раніше, потребує вирішення. Зокрема, щодо медичних засобів, які неможливо придбати в найкоротші терміни під час пандемічної кризи, викликаної вірусом Covid-19.

Ключові слова: Lowell Makes маска, PLA, 3D друк, ULPA фільтр.

\section{D ПЕЧАТЬ «LOWELL MAKES» МАСКИ C PLA НИТЬЮ}

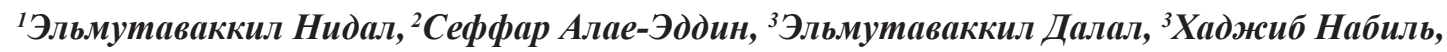 \\ ${ }^{1}$ Белемханнат Самира \\ ${ }^{1}$ Стоматологический консультациионный и лечебный цеентр Касабланки, Касабланка, Марокко \\ ${ }^{2}$ Университетская клиника Ibn Rochd, Касабланка, Марокко \\ з Частный сектор ортодонтии и имплантологии, Касабланка, Марокко \\ nidalelmoutawakkil@yahoo.fr
}

Актуальность. Новый пандемический кризис, вызванный вирусом Covid 19, привел к глобальной нехватке средств индивидуальной защиты, включая маски FFP2, необходимые для использования специалистами, находящимися в прямом контакте c Covid положительными пациентами.

Цель. 3D-печать PLA маски , аналогичной маске FFP2, с добавлением фильтра ULPA (Ultra Low Penetration Air).

Методы. Разработанная маска основана на общих морфологических стандартах маски FFP2. Таким образом, мы загрузили прототип маски «LOWELL MAKES». Мы адаптировали этот прототип к нашим черепно-лицевым размерам с помощью программного обеспечения «Meshmixer». В результате, экспортировали прототип в формат STL для печати с помощью метода FDM (fused deposition modeling / моделирование методом послойного наложения расплавленной полимерной нити) на 3D-принтере «XYZ Junior 1.0», оснащенном PLA (polylactic acid) нитью.

Результаты. Общая продолжительность печати полной маски (внешний слой, основа маски и сетка удерживающего фильтра) составляла около 4 ч 30 мин. Что касается выбора фильтра, мы использовали два варианта: первый - вырезанные, двойные части маски FFP2 использовали в качестве фильтров, второй - использовали коммерческий фильтр ULPA (Ultra Low Penetration Air) или HEPA (High-efficiency particle absorption). Фильтр ULPA теоретически может фильтровать пыль, пыльцу и бактерии 
из воздуха с эффективностью 99,999\% благодаря размеру пор 0,1 микрон. Средний размер вируса Covid-10 составляет около $0,1 \mu \mathrm{m}$, а пористость маски FFP2 позволяет фильтровать частицы диаметром около 0,6 $\mu \mathrm{m}$ в 94\% случаев. Чтобы максимизировать эффект фильтрации при ношении этой маски, мы решили использовать фильтр ULPA, перекрытый фильтром FFP2. Мы проверили плотность этой маски, проверив боковое отсутствие герметичности, удерживая стабилизированный лист на внешней поверхности в результате присасывания во время вдоха. Мы также добавили к краям маски, контактирующей с лицом, периферийное силиконовое уплотнение, полимеризованное на лице, чтобы избежать каких-либо следов или шрамов после удаления этой маски, одновременно увеличивая комфорт практикующего врача. Технология, которую мы предпочли - путем наложения двух фильтров (первый с пористостью $0,6 \mu \mathrm{m}$, а второй $0,1 \mu \mathrm{m}$ ). Это позволило нам усилить фильтрацию и использовать фильтр в течение 40 часов. Общая себестоимость маски составляет около $9 €$.

Выводы. Сообщество открытого программного обеспечения давать возможность популяризировать 3D-печать, вместе с тем позволяет любому владельцу 3D-принтера использовать свое оборудование по сниженной цене. Однако вопрос интеллектуальной собственности по-прежнему требует решения. В частности, в отношении медицинских средств, которые невозможно приобрести в кратчайшие сроки во время пандемического кризиса, вызванному вирусом Covid-19.

Ключевые слова: Lowell Makes маска, PLA, 3D печать, ULPA фильтр. 